\title{
Single primer pair for PCR identification of Candida parapsilosis group I isolates
}

\author{
EUGENIO PONTIERI, CLAUDIA CARACCIOLO, STEFANO BIANCHINI, DOMENICO D'ANTONIO*, \\ GIUSEPPE NOVELLI†, BRUNO DALLAPICCOLA $\$$ and GIUSEPPE CARRUBA
}

Cattedra di Virologia e Micologia Medica, Dipartimento di Medicina Sperimentale, Università degli Studi, I'Aquila, *Servizio di Microbiologia Clinica, Dipartimento di Ematologia ed Oncologia, Ospedale 'Santo Spirito', Pescara, †Cattedra di Genetica Umana Dipartimento di Biopatologia e Diagnostica per Immagini, Università di Roma 'Tor Vergata', †Cattedra di Genetica Umana Università La Sapienza Roma and Istituto CSS-Mendel, Rome, Italy

\begin{abstract}
A DNA fragment, isolated from a genomic DNA mini-library of Candida parapsilosis group I reference strain ATCC 22019, was sequenced and characterised. The fragment was first probed by Southern blotting against a pool of DNA from several yeasts. The hybridisation tests revealed that the probe was specific for strain ATCC 22019 and 49 $(90.74 \%)$ of $54 C$. parapsilosis clinical and soil isolates that were attributed to $C$. parapsilosis group $I$ by the electrophoretic images of their restriction fragment length polymorphisms (RFLPs) and electrophoretic karyotype (EK). The remaining five negative isolates, according to the same criteria, were attributed to group II (one isolate) and III (four isolates). Two primers were selected from the probe DNA sequence and a PCR-based test was developed for specifically detecting $C$. parapsilosis group I isolates, which represent the majority of the common clinical isolates. The PCR assay confirmed the Southern hybridisation results. This PCR assay could be a simple and reproducible tool for the rapid, sensitive and species-specific identification of $C$. parapsilosis major group $\mathrm{I}$ isolates.
\end{abstract}

\section{Introduction}

In recent years, Candida parapsilosis has become increasingly important as a cause of fungaemia or endocarditis [1-4] affecting neutropenic and severely debilitated patients receiving parenteral nutrition [4-6]. Roles for $C$. parapsilosis have been reported also in human vaginitis [7] and lesions of the skin and in cases of onychomycosis [4]. Furthermore, this species produces a biofilm $[8,9]$, which has been suggested as a virulence marker for bacteria [10]. C. parapsilosis isolates have been classified into three genotypically heterogeneous groups by restriction fragment length polymorphism (RFLP) analysis [11]. This grouping was confirmed by random amplified polymorphic DNA (RAPD) analysis [12]. Subsequently, three genetically distinct groups were detected among clinical isolates by

Received 2 May 2000; revised version accepted 10 Nov. 2000.

Corresponding author: Professor G. Carruba (e-mail: carruba @fismedw2.univaq.it). iso-enzyme profile analysis and comparison of the internal transcribed spacer 1 (ITS1) region sequence flanking the 5.8S RNA gene [13]. Moreover, DNADNA re-association and DNA relatedness [14] have confirmed grouping and have affirmed definitively that these groups represent three different species.

Clinically, significant yeasts such as $C$. parapsilosis are commonly identified by standard biochemical kits, which analyse sugar fermentation or assimilation $[15,16]$. Several authors have reported incomplete or incorrect identification of $C$. parapsilosis isolates from human specimens in studies comparing different commercial biochemical diagnostic kits [17-20]. This situation highlights the need to distinguish isolates belonging to the formally named species $C$. parapsilosis by rapid, sensitive and reproducible methods. Molecular methods, particularly PCR-based methods, seem to represent the best choice.

To address this need, a PCR-based tool has been developed for rapid, sensitive and species-specific detection of $C$. parapsilosis group I isolates, represented in the literature [13] and among common clinical isolates. 


\section{Materials and methods}

\section{Organisms and culture conditions}

Table 1 lists all the micro-organisms utilised in this work. The biochemical and pathogenic characters of the 46 clinical and soil isolates designated as SA, HEM and ISS have been described in previous studies [9, 21-23]. All the isolates were identified by standard established laboratory procedures as follows: morphological analysis on corn meal agar, germ-tube formation in serum, carbon source assimilation profile analysis by the ID 32C yeast identification system with an ATB reader (API Systems Vital, bioMérieux Italia, Rome, Italy) (Table 2), and agglutination tests with anti-Candida sera (Candida Check Kit, Iatron Laboratories, Tokyo, Japan). Yeast cells were grown to stationary phase in YPD medium containing yeast extract $1 \% \mathrm{w} / \mathrm{v}$, peptone (Biolife Italiana, Milano, Italy) 2\% w/v and D-glucose (Carlo Erba Reagenti, Milano, Italy) $2 \% \mathrm{w} / \mathrm{v}$ at $30^{\circ} \mathrm{C}$ in a horizontal shaking incubator (Gallenkamp). Bacteria used for cloning - Escherichia coli DH5 $\alpha$ (Stratagene, La Jolla, CA, USA) - were grown in $\mathrm{LB}$ medium with $\mathrm{NaCl}$ (Carlo Erba Reagenti) $1 \% \mathrm{w} / \mathrm{v}$, peptone $1 \% \mathrm{w} / \mathrm{v}$ and yeast extract (Biolife Italiana) $0.5 \% \mathrm{w} / \mathrm{v}$ at $37^{\circ} \mathrm{C}$ in a horizontal shaking incubator.

\section{DNA preparations}

Yeast DNA was prepared as described previously [21]. Single colonies of each isolate were grown to stationary phase (as assessed by measurements of

Table 1. Micro-organisms used in this study

\begin{tabular}{|c|c|c|}
\hline Species & Source & $\begin{array}{l}\text { Strain } \\
\text { designation }\end{array}$ \\
\hline C. albicans & ATCC & $\begin{array}{l}\text { ATCC } 10261 \\
\text { ATCC } 90029\end{array}$ \\
\hline C. krusei & ATCC & ATCC 6258 \\
\hline C. tropicalis & ATCC & ATCC 750 \\
\hline C. glabrata & ATCC & ATCC 90030 \\
\hline Blastoschizomyces capitatus & ATCC & $\begin{array}{l}\text { ATCC } 62963 \\
\text { ATCC } 62964\end{array}$ \\
\hline Saccharomyces cerevisiae & $\mathrm{YPH}^{*}$ & $\begin{array}{l}\text { YPH } 499 \\
\text { YPH } 501\end{array}$ \\
\hline C. parapsilosis & ATCC & $\begin{array}{l}\text { ATCC } 22019 \\
\text { ATCC } 96140 \\
\text { ATCC } 96144\end{array}$ \\
\hline & $\mathrm{CpP}^{\dagger}$ & $\begin{array}{l}\text { CpP1, CpP2, CpP3, } \\
\text { CpP6, } \\
\text { CpPFA, pPGH, } \\
\text { CpP5,CpPO }\end{array}$ \\
\hline & ISS $^{+}$ & Soil isolates (3) \\
\hline & SA & Vaginal isolates (20) \\
\hline & HEM & Blood isolates (23) \\
\hline E. coli & $\ldots$ & $\mathrm{DH} 5 \alpha^{\dagger}$ \\
\hline
\end{tabular}

ATCC, American Type Culture Collection.

*From Stratagene.

${ }^{\dagger}$ C. parapsilosis isolates from Pisa University, Pisa, Italy: CpP 1, 2 , 3, 6, FA, GH from Neonatology Care Unit, CpP1 and CpP2 isolated from the same patient, conjunctival buffer and blood, respectively; $\mathrm{CpP} 5$ from a patient in the Infectious Disease Unit; CpPO from a wash-basin in the Ophthalmology Department.

Isolates ISS, SA and HEM were analysed previously for genetic and phenotypic characters [9, 22, 23]. optical density of cultures) in $10 \mathrm{ml}$ of YPD medium at $30^{\circ} \mathrm{C}$ in $50-\mathrm{ml}$ sterile disposable polypropylene tubes $(30 \times 115 \mathrm{~mm})$. For spheroplast formation, the cells were washed in sterile distilled water and resuspended in $1.2 \mathrm{M} \mathrm{D}$-sorbitol and $0.1 \mathrm{M}$ EDTA, $\mathrm{pH} 7.5$, with $25 \mu \mathrm{l}$ of Lyticase $(4000 \mathrm{U} / \mathrm{mg}$; Lyticase, Sigma) $5 \mathrm{mg} / \mathrm{ml}$ solution and incubated at $37^{\circ} \mathrm{C}$ for $1 \mathrm{~h}$. The spheroplasts were centrifuged and incubated in lysis buffer $(50 \mathrm{mM}$ Tris-HCl, $20 \mathrm{mM}$ EDTA and sodium dodecyl sulphate $1 \%, \mathrm{pH} 7.5$ ) for $30 \mathrm{~min}$ at $65^{\circ} \mathrm{C}$. Then $1.5 \mathrm{ml}$ of $5 \mathrm{M}$ potassium acetate were added and the mixture was kept on ice for $1 \mathrm{~h}$ and then centrifuged. The pellet was discarded and the supernate was treated for DNA purification [24]. Plasmid mini-preparations from bacterial cells were performed with Qiagen DNA plasmid extraction kits according to the manufacturer's instructions (Qiagen GmbH, Hilde, Germany).

\section{Construction of C. parapsilosis genomic mini- library}

Genomic DNA $(10 \mu \mathrm{g})$ from $C$. parapsilosis ATCC 22019 was digested with HindIII (Boehringer Mannheim GmbH, Mannheim, Germany) and electrophoresed. The small-size portion of the resulting fragments, ranging in size from 564 to $2000 \mathrm{bp}$, was purified from an agarose $0.8 \% \mathrm{w} / \mathrm{v}$ gel (BioRad, Segrate, Milano, Italy) with a Jet-Sorb gel extraction kit (Genomed $\mathrm{GmbH}$, Bad Oeynhamen, Germany) and ligated into the unique HindIII cloning site of p-Bluescript $\mathrm{SK}^{-}$ (Stratagene) previously treated with calf intestinal alkaline phosphatase (CIP) (Stratagene) [25]. The ligation mixture was used for transforming $E$. coli DH5 $\alpha$ (Stratagene) competent cells in a Gene-Pulser (BioRad). Ampicillin-resistant transformants were selected on AMP (Boehringer Mannheim $\mathrm{GmbH}$ ) $50 \mu \mathrm{g} / \mathrm{ml}$ agar plates supplemented with X-gal (Bromo-4-chloro-3-indolyl- $\beta$-D-galactopyranoside) $\quad 40 \mu \mathrm{g} /$ $\mathrm{ml}$ and IPTG (isopropyl- $\beta$-D-galactopyranoside) (Boehringer Mannheim $\mathrm{GmbH}) 40 \mu \mathrm{g} / \mathrm{ml}$ for white/blue phenotype screening of putative positive clones (50100 total colonies for plates). Cells from white colonies were screened further by PCR with the M13 universal forward and -20 reverse primers (Stratagene) homologous to the polylinker region of p-Bluescript to assess the presence of the recombinant fragments. The white colonies containing recombinant plasmids, with $C$. parapsilosis inserts, were pooled to constitute the genomic mini-library.

\section{Agarose plug preparation and electrophoretic karyotyping}

Agarose plugs were prepared from all the yeast isolates (ATCC or clinical strains) as reported previously [23]. Samples were examined for electrophoretic karyotypes by pulsed-field electrophoresis with a CHEF Mapper (BioRad) [26]. The electrophoretic running conditions were: a pulse-time from $60 \mathrm{~s}$ to $500 \mathrm{~s}$ at $120 \mathrm{~V}$ constant voltage for $72 \mathrm{~h}$ in agarose $1 \% \mathrm{w} / \mathrm{v}$ gel (BioRad), 
Table 2. Attribution of the ID $32 \mathrm{C}$ code to $C$. parapsilosis isolates

\begin{tabular}{|c|c|c|c|c|c|}
\hline ID 32C Code & Soil isolates & Vaginal isolates & Blood isolates & ATCC strains & Pisa strains \\
\hline $55473503-17$ & $\begin{array}{l}\text { ISS } 4879 \text {, } \\
\text { ISS } 4884\end{array}$ & $\begin{array}{l}\text { SA } 17 \text {, SA } 19, \text { SA } 23 \text {, SA } 28 \text {, } \\
\text { SA } 36 \text {, SA } 38 \text {, SA 42, SA } 197 \text {, } \\
\text { SA 297, SA 355, SA } 365 \text {, } \\
\text { SA 381, SA 392, SA } 393 \text {, } \\
\text { SA } 447 \text {, SA 461 }\end{array}$ & $\begin{array}{l}\text { HEM 1, HEM 2, HEM 3, } \\
\text { HEM 4, HEM 9, HEM 10, } \\
\text { HEM 11, HEM 12, HEM 13, } \\
\text { HEM 14, HEM 15, HEM 18, } \\
\text { HEM 19, HEM 20, HEM 21, } \\
\text { HEM 23, HEM 24, HEM 25, } \\
\text { HEM } 26\end{array}$ & $\begin{array}{l}\text { ATCC 22019, } \\
\text { ATCC } 96140\end{array}$ & CpP6 \\
\hline $55473503-13$ & & & & & FA \\
\hline 55473503-15 & & SA 139 & HEM 8, HEM 17 & & \\
\hline $55473507-17$ & & & HEM 22 & & \\
\hline $55473507-13$ & & & HEM 16 & & \\
\hline $55477503-15$ & & SA 383 & & & \\
\hline $55477503-17$ & & SA 342 & & & GH \\
\hline 55413507 & ISS 4888 & SA 25 & & & \\
\hline $55443501-15$ & & & & ATCC 96144 & $\begin{array}{l}\text { СpPO, СpP1, CpP2, } \\
\text { СpP3, СpP5 }\end{array}$ \\
\hline
\end{tabular}

Isolates found to be negative in hybridisation or PCR tests, or both, are shown in bold type.

running buffer $0.5 \times$ TBE, $45 \mathrm{mM}$ Tris base, $45 \mathrm{mM}$ boric acid and $1 \mathrm{mM}$ EDTA at a constant temperature of $14^{\circ} \mathrm{C}$. Images of the gels were obtained by Gel-Doc 2000 (BioRad). CHEF gels, previously treated for 10 min with $0.2 \mathrm{M} \mathrm{HCl}$, were denatured in $0.5 \mathrm{M}$ $\mathrm{NaOH}, 1.5 \mathrm{M} \mathrm{NaCl}$, neutralised in $1.5 \mathrm{M} \mathrm{NaCl}, 0.5 \mathrm{M}$ Tris- $\mathrm{HCl}, 0.1 \mathrm{mM}$ EDTA, $\mathrm{pH} 7.2$, and transferred to a nylon Hybond-N membrane (Amersham Italia, Milan, Italy) in $10 \times \mathrm{SSC}, 1.5 \mathrm{M} \mathrm{NaCl}, 165 \mathrm{mM}$ tri-sodium citrate 2-hydrate, $\mathrm{pH} 7$, for Southern hybridisation [25].

\section{HindIII restriction endonuclease digestion}

For each isolate, 5-6 $\mu \mathrm{g}$ of DNA were digested with HindIII (Boehringer Mannheim $\mathrm{GmbH}$ ) and electrophoresed in agarose $1 \% \mathrm{w} / \mathrm{v}$ gel (BioRad) in $1 \times \mathrm{TBE}$ buffer, $89 \mathrm{mM}$ Tris-base, $89 \mathrm{mM}$ boric acid and $2 \mathrm{mM}$ EDTA. Gels were photographed by Gel-Doc 2000, denatured in $0.5 \mathrm{M} \mathrm{NaOH}, 1.5 \mathrm{M} \mathrm{NaCl}$, neutralised in $1.5 \mathrm{M} \mathrm{NaCl}, 0.5 \mathrm{M}$ Tris-HCl, $1 \mathrm{mM}$ EDTA, $\mathrm{pH}$ 7.2, and transferred to a nylon Hybond- $\mathrm{N}$ membrane in 10 $\times \mathrm{SSC}, 1.5 \mathrm{M} \mathrm{NaCl}, 0.165 \mathrm{M}$ tri-sodium citrate 2hydrate, $\mathrm{pH} 7$, for Southern hybridisation [25].

\section{Southern blot hybridisation analysis}

Positive clones from the constructed genomic minilibrary were used in hybridisation experiments to test their species-specificity for $C$. parapsilosis group I isolates. Plasmids containing fragments were digested with HindIII to excise the inserts and these, after electrophoresis, were purified from agarose (BioRad) $0.8 \% \mathrm{w} / \mathrm{v}$ gel in a Jet-Sorb gel extraction kit (Genomed $\mathrm{GmbH})$. The fragments were radiolabelled with $[\alpha-$ ${ }^{32} \mathrm{P}$ ]dCTP (Amersham Italia) by random primer extension reaction with a Rediprime II labelling kit (Amersham Italia) as recommended by the manufacturer and used in high stringency hybridisation conditions to probe the electrophoretic karyotype (EK) and the restriction endonuclease analysis (REA) constructed Southern blots for all strains. One of the fragments, found to be specific for C. parapsilosis group I, was selected for sequence analysis because it had a short sequence and appeared not to be repetitive, but was a single copy sequence and did not correspond to the size of HindIII mtDNA fragments analysed previously [21]. The plasmid containing this fragment was named $\mathrm{pBHCpC1}$ (p-Bluescript HindIII C. parapsilosis clone 1).

\section{Sequence analysis}

The complete DNA sequence of the $\mathrm{CpC} 1$ fragment was obtained by using the M13 universal forward and -20 reverse primers reading the p-Bluescript (SK-) plasmid sequence from the polylinker. The primers were end-labelled $(10 \mathrm{pmol})$ with $\left[\gamma_{-}{ }^{32} \mathrm{P}\right] \mathrm{ATP}$ and T4 polynucleotide kinase (HT Biothechnology, Cambridge) and used in PCR sequence reactions in a Thermo Sequenase $^{\mathrm{TM}}$ cycle sequencing kit (Amersham Pharmacia Biotech, Cleveland, OH, USA). To complete the sequence, new oligodeoxynucleotides (Gibco, Life Technologies Italia, San Giuliano Milanese, Milano Italy) were selected from the sequenced regions of the fragment: Fw1 (5'-GTG AGA GAT GTT TGT AAT TGC GAG AAC C-3', bp 103-130), Rv1 (5'-GCA TTA TTC GGA CGT TCA ACC CG-3', bp 775-753), Rv2 (5'-CCC TAA CAG TAA TAA CGC TC-3', bp 514-495), Rv3 (5'-GCT CAA GCA ATG GAA GAC AGG TTG G-3', bp 664-639).

\section{Characterisation of $\mathrm{CpCl}$}

The DNA fragment was sequenced and characterised (Fig. 1) and found to be $800 \mathrm{bp}$ in size. This sequence, checked by Blast v. 2 search [27], did not exhibit homology with other known sequences. The sequence was analysed with OMIGA v.1.1.3 (Oxford Molecular, Oxford). A GA repeat and possible TATA and CCAAT boxes were found (these sites are underlined in Fig. 1), but no relevant ORFs were found. The sequence was submitted to GenBank: accession no. AF207607. 


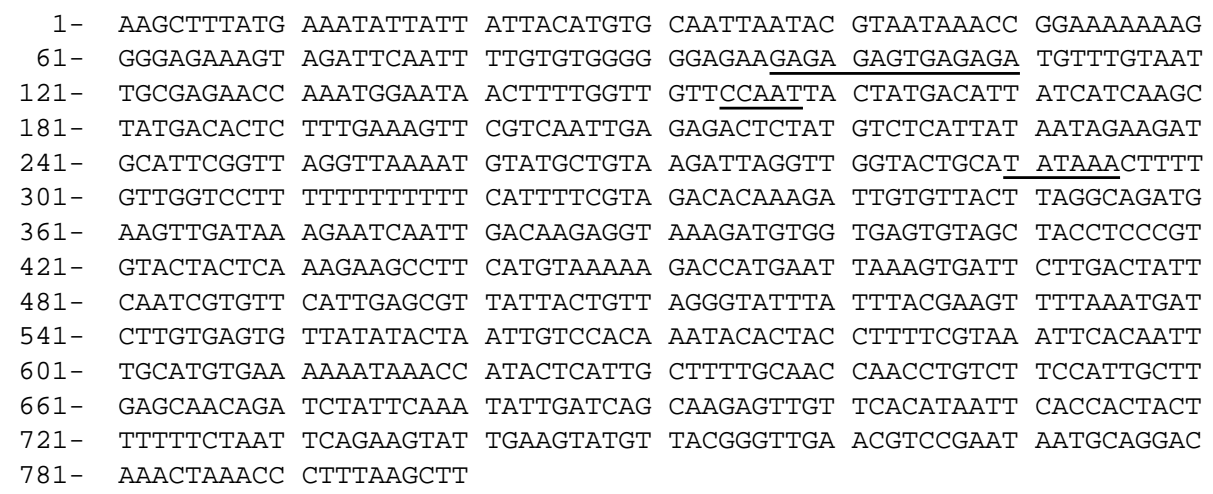

Fig. 1. The complete $800-\mathrm{bp} \mathrm{DNA}$ sequence of the $\mathrm{CpC} 1$ fragment. Underlined text indicates the CCAAT and TATA hypothetical boxes and the GA repeat.

\section{PCR analysis}

DNA from each isolate $(100 v \mathrm{~g})$ was added to a PCR master mix consisting of $5 \mu \mathrm{l}$ of $10 \times \mathrm{PCR}$ buffer (100 mM Tris-HCl, pH 9.0, $15 \mathrm{mM} \mathrm{MgCl}_{2}, 0.5 \mathrm{M} \mathrm{KCl}$, $1 \%$ Triton $\mathrm{X}-100,0.1 \% \mathrm{w} / \mathrm{v}$ as stabilizer), $7 \mu \mathrm{l}$ of a mixture of $178 \mu \mathrm{M}$ deoxynucleoside triphosphates (equimolar concentration of each dATP, dCTP, dGTP and dTTP), 50 pmol of the primers Fw1 and Rv1 and $1 \mathrm{U}$ of Super Taq (HT Biotechnology) adjusted to a final volume of $50 \mu \mathrm{l}$ with sterile distilled water. PCR was performed in a Techne Thermal Cycler (Progene Techne, Duxford Cambridge) with 3 min initial denaturation at $94^{\circ} \mathrm{C}$ and 25 cycles as follows: $1 \mathrm{~min}$ at $94^{\circ} \mathrm{C}, 1 \mathrm{~min}$ at $65^{\circ} \mathrm{C}$ and $1 \mathrm{~min}$ and $30 \mathrm{~s}$ at $72^{\circ} \mathrm{C}$. The last cycle was followed by a supplemental $7 \mathrm{~min}$ extension at $72^{\circ} \mathrm{C}$ and then cooled to $10^{\circ} \mathrm{C}$. PCR products $(6.5 \mu \mathrm{l})$ were electrophoresed in agarose $1.2 \%$ $\mathrm{w} / \mathrm{v}$ gel $(\mathrm{BioRad})$ in $1 \times \mathrm{TBE}$ buffer and images were captured by Gel-Doc 2000. Gels denatured with $0.5 \mathrm{M}$ $\mathrm{NaOH}, 1.5 \mathrm{M} \mathrm{NaCl}$ and neutralised with $0.5 \mathrm{M}$ Tris
$\mathrm{HCl}, 1.5 \mathrm{M} \mathrm{NaCl}$ and $0.1 \mathrm{mM}$ EDTA, $\mathrm{pH}$ 7.2, were transferred on to Hybond-N nylon membrane by capillarity $(10 \times \mathrm{SSC})$. The internal primer Rv2 was end-labelled $(300 \mathrm{pmol})$ with $\left[\gamma_{-}{ }^{32} \mathrm{P}\right] \mathrm{ATP}$ with T4 polynucleotide kinase (HT Biotechnology) and used as a hybridisation probe to control the species-specificity of the PCR test confirming the presence or absence of the expected fragments.

\section{Results}

\section{Southern blot analysis}

Hybridisation with the probe $\mathrm{CpCl}$ on to Southern blots of EK and REA was positive for strain ATCC 22019, and for $49(90.74 \%)$ of 54 C. parapsilosis clinical and soil isolates (Figs. 2 and 3). ATCC 96140 and ATCC 96144 reference strains of $C$. parapsilosis group II and III were not detected. The five negative isolates in the $C$. parapsilosis pool were strains

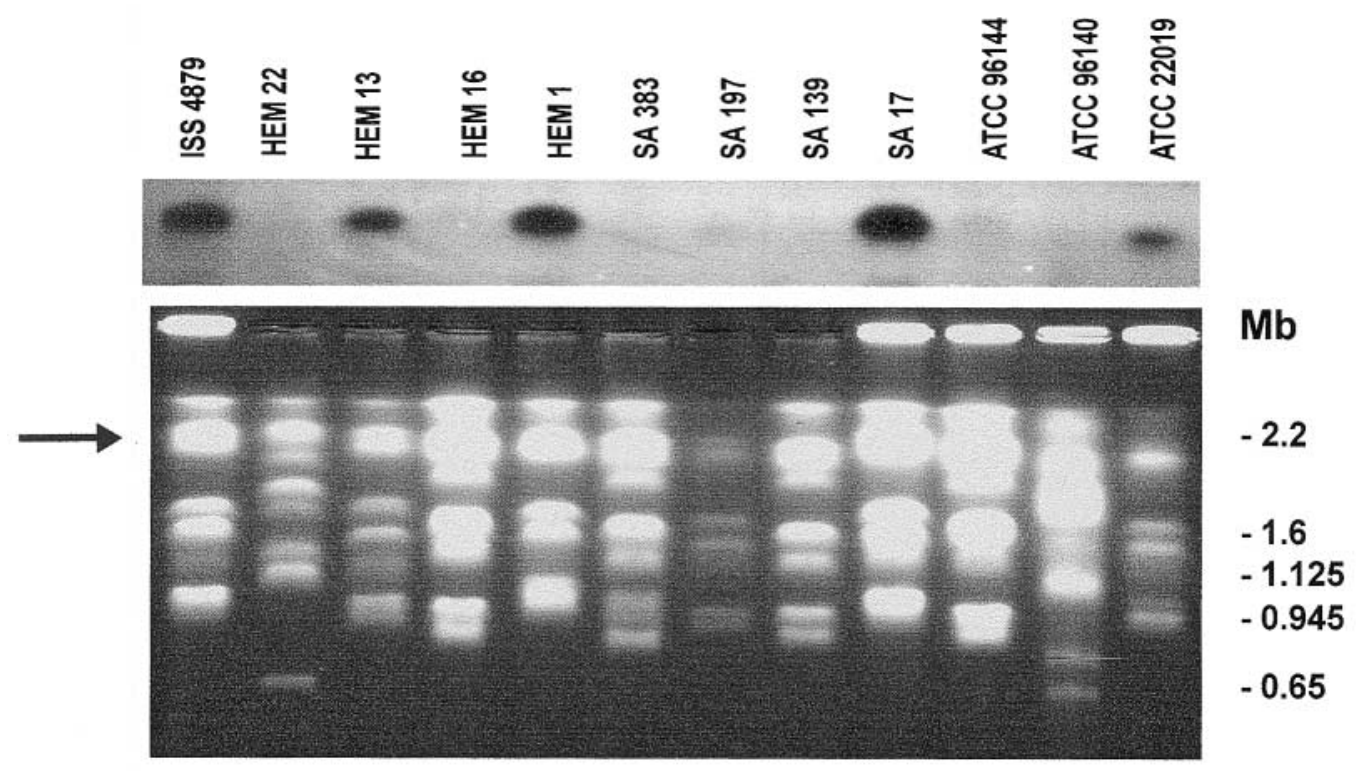

Fig. 2. CHEF gel and hybridisation results obtained with representative isolates. The ATCC representative strains of the three groups are compared with several of the C. parapsilosis isolates screened (see Table 1 for complete list). The arrow indicates the chromosomal band positive to hybridisation. Note the faint lane of strain SA 197, which corresponds to a faint hybridisation band. 


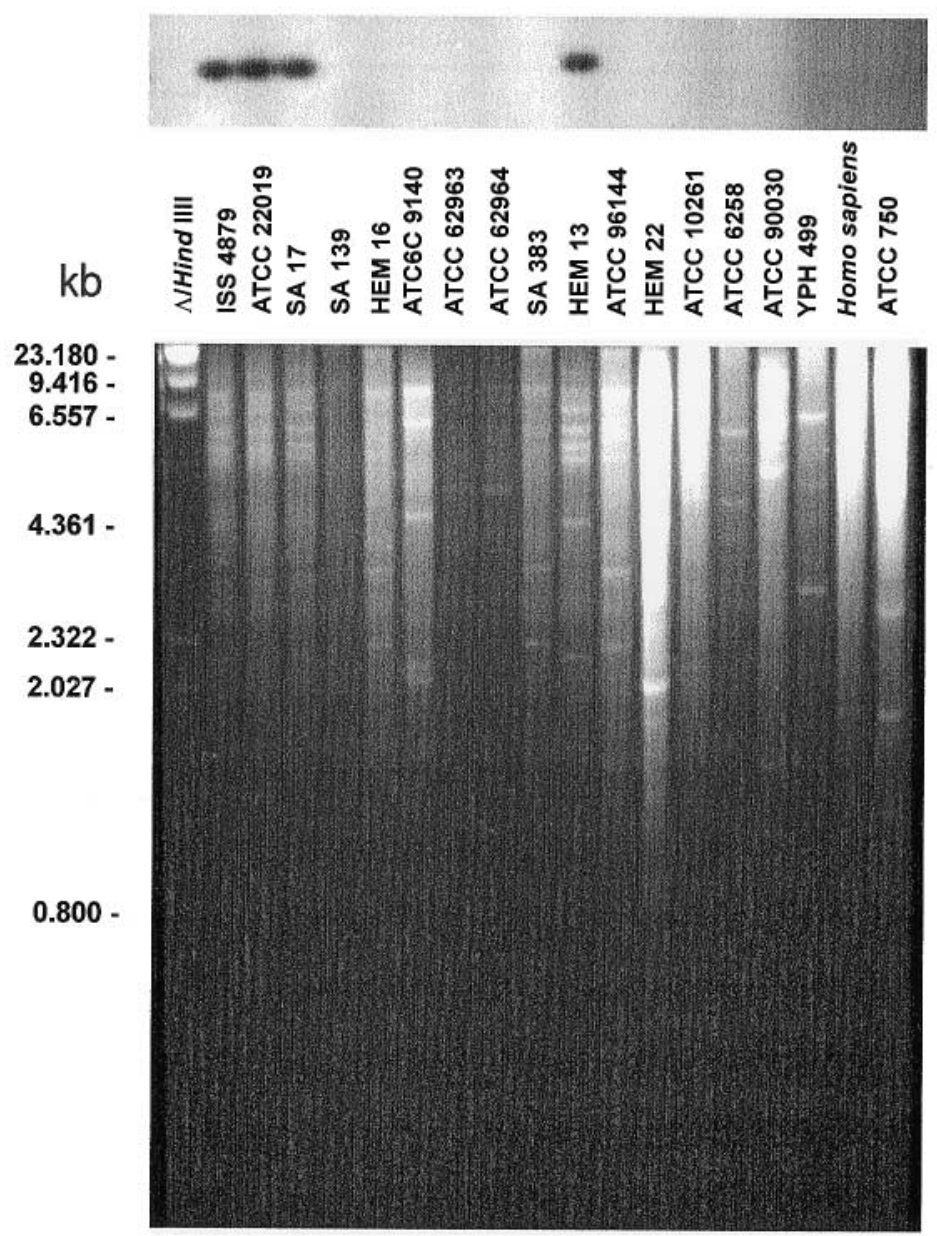

Fig. 3. HindIII RFLP gel and hybridisation results of representative isolates of the whole pool tested (see Table 1 for complete list). The size marker is $\lambda /$ HindIII.

HEM16, HEM22, SA139, SA383 and CpP5. All the other species of Candida or yeasts tested and DNA from Homo sapiens gave negative results (Fig. 3). The positive hybridisation signal detected by the probe on to Southern blots of CHEF gels, under the electrophoretic conditions employed, seems to correspond to the third major chromosomal band of all the positive isolates. Hybridisation of the probe on REA Southern blots revealed a positive band of $800 \mathrm{bp}$ for the expected isolates (Fig. 3). By comparison of EK or HindIII REA profiles, or both, it was possible to attribute strain HEM 22 to group II and strains SA 139, SA 383, HEM 16 and CpP5 to group III.

\section{PCR analysis}

Primers Fw1 and Rv1 were selected for PCR analysis. The expected fragment of 673 bp was detected only for strain ATCC 22019 (Fig. 4) and 49 (90.74\%) of 54 clinical and soil isolates, confirming the Southern hybridisation experiments. Strains SA 139, SA 383, HEM 16, HEM 22 and CpP5 gave negative results (Fig. 5). The two strains ATCC 96140 and ATCC 96144, representative of $C$. parapsilosis groups II and III respectively, and the other Candida or yeast species and human DNA also gave negative results (Fig. 4). The results of PCR tests were confirmed by oligohybridisation with the primer Rv2 internal to the sequence of Fw1-Rv1 fragment (Fig. 4).

\section{Discussion}

C. parapsilosis is an ever-increasing cause of fungaemia in patients with various disorders [1-5] or undergoing hyperalimentation therapy employing central venous catheters (CVC) $[1,6]$. In some epidemiological studies this fungus represented the most prevalent cause of candidaemia with respect to other Candida spp. [1]. The species $C$. parapsilosis is normally identified by commercial biochemical kits. Several authors have reported misidentification of $C$. parapsilosis from clinical specimens in studies comparing these different kits [17-20]. This species can be misidentified as other Candida spp. or as a yeast belonging to another genus [17-20]. Moreover, the formally named species $C$. parapsilosis consists of three distinct genetic groups [13,14] represented by three ATCC strains (22019, 96140 and 96144, respectively). C. parapsilosis isolates can be assigned 
a
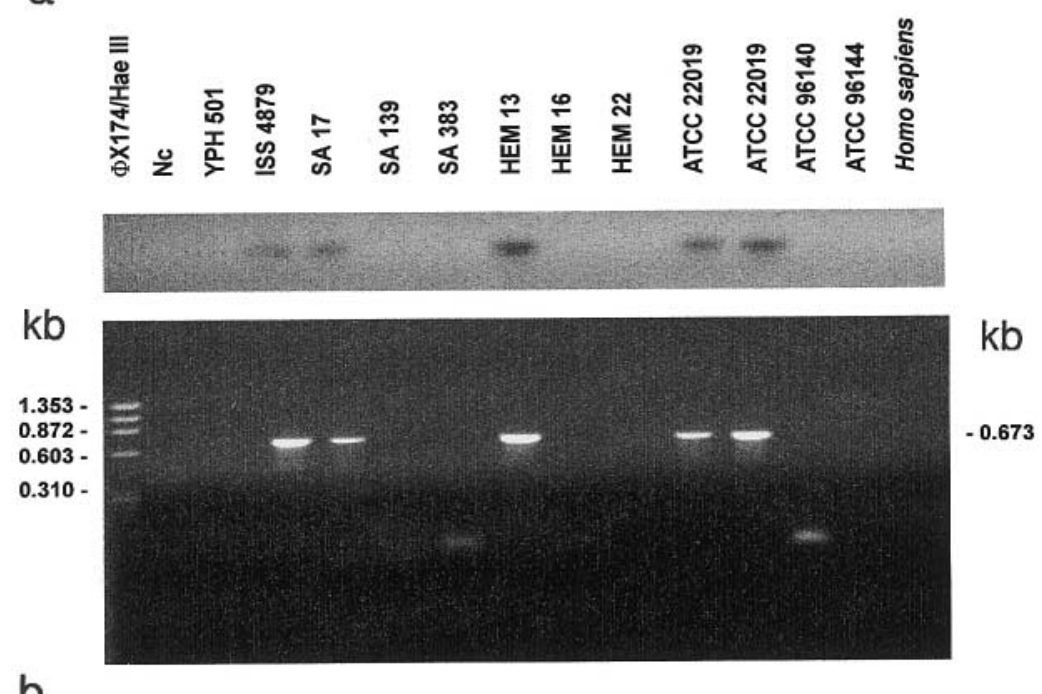

b
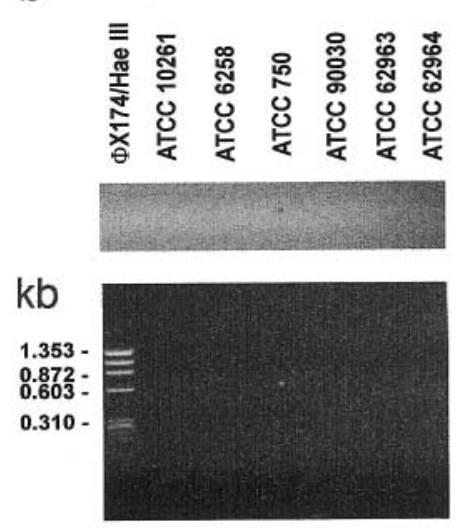

Fig. 4. Representative PCR test. (a) ATCC strains representative of the three groups of C. parapsilosis, the negative control (Nc) and several of the C. parapsilosis isolates screened are evident. (b) The same PCR on ATCC strains of other Candida or Blastoschizomyces capitatus isolates; the relative negative control is shown in (a). The size marker is $\Phi \times 174 /$ Hae III.

to one of the three groups by sequencing the internally transcribed spacer region 1 (ITS1) flanking the $5.8 \mathrm{~S}$ RNA gene [13], or by analysing the nuclear DNA base composition, DNA-DNA re-association and DNA RFLPs [14]. The comparison of DNA relatedness has clarified that the three groups are three distinct species, with $<25 \%$ DNA identity between them [14]. In the light of this information it is paramount that clinically significant yeasts are identified accurately and that the characterisation of $C$. parapsilosis strains at a biotype and clonal level will be very useful for epidemiological studies. Molecular methods $[13,14]$ appear to discriminate between the three groups, but do not appear to be suitable for routine use. The PCR test described here represents a reproducible and, compared with the previously reported molecular methods [13,14], a more rapid and easier tool for identifying $C$. parapsilosis group I isolates. The PCR test has enabled the reproducible identification of all isolates belonging to C. parapsilosis group I. Most clinical isolates appear to be incorporated in this group, accounting for $90.74 \%$ in the present study and for $73.33 \%$ of C. parapsilosis isolates analysed by Lin et al. [13]. The former study found that group III contained more isolates (four isolates) with respect to group II (one isolate), unlike the reported data of Lin et al. [13] (10 isolates in group II and 2 isolates in group III). This finding could suggest regional or local differences in the distribution of these two minor groups. The development of a PCR test for complete identification of all the three groups (species) is necessary for a correct diagnosis and characterisation of pathological characteristics.

The present study did not analyse phenotypic or epidemiological differences among the isolates, being concerned only with diagnostic aspects. On the basis of the data reported previously regarding the ISS, SA and HEM isolates of the pool analysed $[9,22]$ it can be concluded that no specific differences exist that indicate more pathogenicity in a particular group with respect to the others. However, group I is the only group that includes isolates that are not slime producers (all the isolates designed ISS and the majority of the SA isolates) [9], the four isolates of groups II and III 


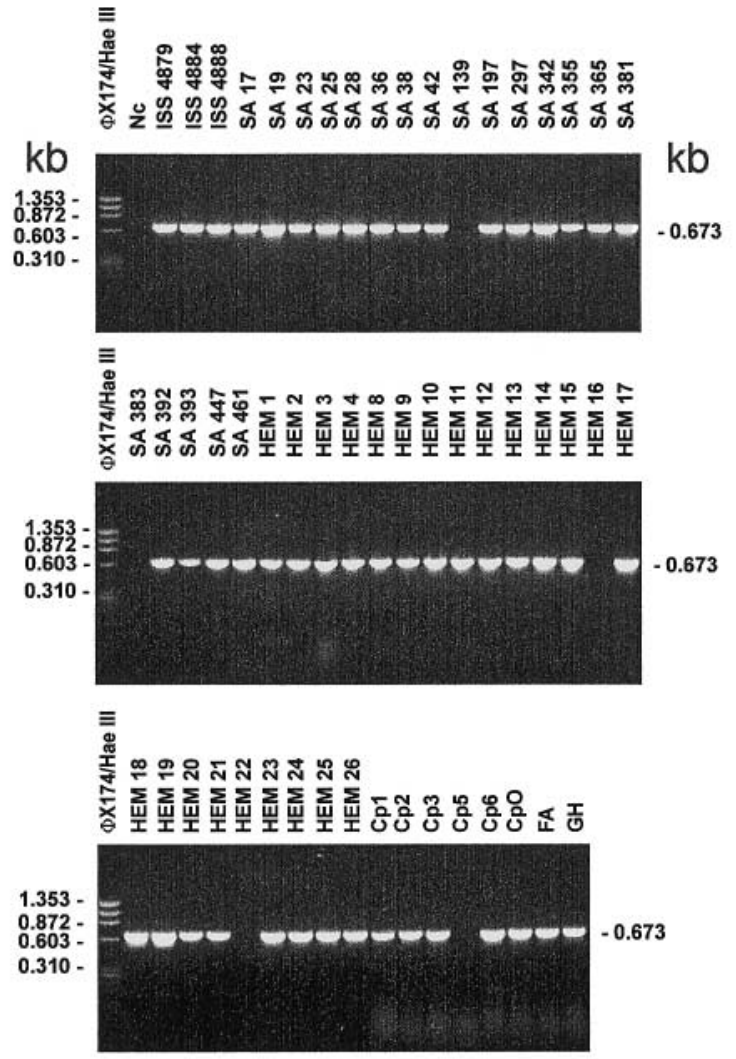

Fig. 5. All the 54 clinical and soil isolates of $C$. parapsilosis analysed are represented in these three panels; the relative negative control (Nc) is shown in (a). The size marker is $\Phi \times 174 /$ Hae III.

were able to grow in agar plates supplemented with 5fluorocytosine $(25 \mu \mathrm{l} / \mathrm{ml})$ [22] and strains HEM 16 and HEM 22 (group III and II, respectively) were nonproteolytic for acid (aspartyl) proteinase secretion [22]. The three groups should be analysed further to determine their peculiar epidemiological and pathogenic characteristics.

This work was supported by MURST (Programma di Ricerca Scientifica di Rilevante Interesse Nazionale: Unità G. Carruba, prot. 9806297296-008). We are grateful to Professor S. Senesi for providing the $\mathrm{CpP}$ isolates of $C$. parapsilosis.

\section{References}

1. Girmenia C, Martino P, De Bernardis F et al. Rising incidence of Candida parapsilosis fungemia in patients with hematological malignancies: clinical aspects, predisposing factors, and differential pathogenicity of the causative strains. Clin Infect Dis 1996; 23: 506-514

2. Komshian SV, Uwaydah AK, Sobel JD, Crane LR. Fungemia caused by Candida species and Torulopsis glabrata in the hospitalized patient; frequency, characteristics, and evaluation of factors influencing outcome. Rev Infect Dis 1989; 11: 379-390.

3. Meunier-Carpentier F, Kiehn TE, Armstrong D. Fungemia in the immunocompromised host: changing patterns, antigenemia, high mortality. Am J Med 1981; 71: 363-370.
4. Weems JJ. Candida parapsilosis: epidemiology, pathogenicity, clinical manifestations, and antimicrobial susceptibility. Clin Infect Dis 1992; 14: 756-766.

5. Plouffe JF, Brown DG, Silva JJ, Eck T, Stricof RL, Fekety FR. Nosocomial outbreak of Candida parapsilosis fungemia related to intravenous infusions. Arch Intern Med 1977; 137: $1686-1689$

6. Weems JJ, Chamberlain ME, Ward J, Willy M, Padhye AA, Solomon SL. Candida parapsilosis fungemia associated with parenteral nutrition and contaminated blood pressure transducers. J Clin Microbiol 1987; 25: 1029-1032.

7. De Bernardis F, Morelli L, Ceddia T, Lorenzini R, Cassone A. Experimental pathogenicity and acid proteinase secretion of vaginal isolates of Candida parapsilosis. J Med Vet Mycol 1990; 28: 125-137.

8. Branchini ML, Pfaller MA, Rhine-Chalberg J, Frampong T, Isenberg HD. Genotypic variation and slime production among blood and catheter isolates of Candida parapsilosis. J Clin Microbiol 1994; 32: 452-456.

9. Pontieri E, Sferra R, Vetuschi A, Gaudio E, Carruba G. Variation of slime production and ultrastructural analysis in clinical and soil isolates of Candida parapsilosis. Microbial Ecol Hlth Dis 1998; 10: 17-24.

10. Davemport DS, Massanari RM, Pfaller MA, Bale MJ, Streed SA, Hierholzer WJ. Usefulness of a test for slime production as a marker for clinically significant infections with coagulase-negative staphylococci. J Infect Dis 1986; 153: 332-339.

11. Scherer S, Stevens DA. Application of DNA typing methods to epidemiology and taxonomy of Candida species. $J$ Clin Microbiol 1987; 25: 675-679.

12. Lehmann PF, Lin D, Lasker BA. Genotypic identification and characterization of species and strains within the genus 
Candida by using random amplified polymorphic DNA. J Clin Microbiol 1992; 30: 3249-3254.

13. Lin D, Wu L-C, Rinaldi MG, Lehmann PF. Three distinct genotypes within Candida parapsilosis from clinical sources. J Clin Microbiol 1995; 33: 1815-1821.

14. Roy B, Meyer SA. Confirmation of the distinct genotype groups within the form species Candida parapsilosis. J Clin Microbiol 1998; 36: 216-218.

15. Larone DH. Medically important fungi: a guide to identification, 2nd edn. Washington, DC, American Society for Microbiology. 1993.

16. Warren NG, Hazen KC. Candida, Cryptococcus and other yeasts of medical importance. In: Murray PR, Baron EJ, Pfaller MA, Tenover FC, Yoken RH (eds) Manual of clinical microbiology, 6th edn. Washington, DC, American Society for Microbiology. 1995: 723-737.

17. Fenn JP, Segal H, Barland B et al. Comparison of updated vitek yeast biochemical card and API 20C yeast identification systems. J Clin Microbiol 1994; 32: 1184-1187.

18. Heelan JS, Sotomayor E, Coon K, D'Arezzo JB. Comparison of the rapid yeast plus panel with the API 20C yeast system for identification of clinically significant isolates of Candida species. J Clin Microbiol 1998; 36: 1443-1445.

19. Wadlin JK, Hanko G, Stewart R, Pape J, Nachamkin I Comparison of three commercial systems for identification of yeasts commonly isolated in the clinical microbiology laboratory. $J$ Clin Microbiol 1999; 37: 1967-1970.
20. Ramani R, Gromadzki S, Pincus DH, Salkin IF, Chaturvedi V. Efficacy of API 20C and ID 32C systems for identification of common and rare clinical yeast isolates. $J$ Clin Microbiol 1998; 36: 3396-3398.

21. Carruba G, Pontieri E, De Bernardis F, Martino P, Cassone A. DNA fingerprinting and electrophoretic karyotype of environmental and clinical isolates of Candida parapsilosis. J Clin Microbiol 1991; 29: 916-922

22. Cassone A, De Bernardis F, Pontieri E et al. Biotype diversity of Candida parapsilosis and its relationship to the clinical source and experimental pathogenicity. $J$ Infect Dis 1995; 171: 967-975.

23. Pontieri E, Gregori L, Gennarelli M et al. Correlation of Sfi I macrorestriction endonuclease fingerprint analysis of Candida parapsilosis isolates with source of isolation. J Med Microbiol 1996; 45: 173-178.

24. Sherman F, Fink GR, Hicks JB. Laboratory course manual for methods in yeast genetics. Cold Spring Harbor, NY, Cold Spring Harbor Laboratory. 1986.

25. Sambrook J, Fritsch EF, Maniatis T. Molecular cloning: a laboratory manual, 2nd edn. Cold Spring Harbor, NY, Cold Spring Harbor Laboratory. 1989.

26. Vollrath D, Davis RW. Resolution of DNA molecules greater than 5 megabases by contour-clamped homogeneous electric fields. Nucleic Acid Res 1987; 15: 7865-7876.

27. Altschul SF, Madden TL, Schäffer AA et al. Gapped BLAST and PSI-BLAST: a new generation of protein database search programs. Nucleic Acids Res 1997; 25: 3389-3402. 